\title{
SOME MATERIALS OF LOW THERMAL CONDUCTIVITY.
}

\author{
By Ezer Griffiths, D.Sc., National Physical Laboratory.
}

Some Materials of Low Thermal Conductivity.-From the point of view of the refrigerating engineer, the ideal material for cold storage insulation would be an assemblage of minute gas cells totally enclosed in a light framework impervious to moisture. Hermetical sealing of the cells is essential, for a water logged material is useless for insulation purposes. Besides the fact that the value of the thermal conductivity of water is about ten times that of the conductivity of the materials usually employed for insulating purposes, the presence of moisture is liable to set up decomposition in substances of organic origin. Consequently many excellent thermal insulators, such as cotton waste and wood sawdust, are ruled out on account of their rapid deterioration in the presence of water.

Another important factor which has to be considered in assessing the value of an insulator, especially for marine work, is the weight per cubic foot of the material. A modern refrigerating ship of 6400 tons requires about 400 tons of cork. ${ }^{1}$ So a saving of a few per cent. is well worth while.

A material of low weight per cubic foot has the additional advantage

1 The following particulars concerning two ships of the Nelson Line were kindly supplied by Mr. A. R. 'T. Woods, M.I.Mech.E., M.I.N.A.

Ship built in rgrr. Registered gross tonnage 7490 tons. Insulated throughout :Approx. Weights.

Hull, engines and boilers
Refrig. machinery and brine piping, etc. . . . . . . 4490 tons

Insulation (silicate cotton) and timber . . . . ro5o ,

Empty ship, total weight $=6150$ tons.

Total capacity of cargo spaces $=328,980$ cubic feet

" " " " $", \quad, \quad, \quad=3$ " $=3300$ tons chilled meat.

Ship built in r920. Registered gross tonnage $844^{2}$ tons. Insulated throughout :Approx. Weights.

Hull, engines and boilers

Refrig. machinery and brine piping, etc.

Insulation, granulated cork

" timber.

Empty ship, total weight $=6400$ tons.

Total capacity of cargo spaces $=44^{\mathrm{I}} 4,570$ cubic feet.

" , , , ",$\quad=394^{\circ}$ tons chilled meat.

," ", ", ", = $" 4 \mathrm{r} 50$," frozen meat.

Silicate cotton packs . . . . . $22 \mathrm{lbs}$ per cubic foot.

Cork (granulated) " • . . . . $7,,, \quad, \quad$, 
that the heat which has to be abstracted in cooling down the stores is less, and this leads to economy of working.

The heat insulators in common use at the present day are slab cork, granulated cork, slag wool, and charcoal. These are so well known as not to need further description ${ }^{1}$ and the purpose of the present communication is to bring to the attention of refrigerating engineers a few materials which may be worthy of study under practical cold storage conditions, for they possess at least one essential characteristic of a cold stores insulator, namely, low thermal conductivity.

Expanded Rubber.-Methods have been devised for the conversion of rubber into a highly cellular form, the resulting product having an exceedingly low density.

When viewed under a low power microscope, the material shows a structure apparently made up of minute cells bounded by rubber membranes. The cellular structure of the material immediately suggests the possibility of its use as a heat insulator.

The small samples we obtained differed considerably as regards density and presumably this variable can be controlled by the method of manufacture as well as its physical state, whether soft or hard. Samples of the soft variety varied in density from 0.059 to 0.12 C.G.S. units $(3.7$ to $7.5 \mathrm{lbs}$. per cubic foot), while a hard variety resembling ebonite had a density of 0.17 (10.6 lbs. per cubic foot). ${ }^{2}$

It would be a matter of considerable theoretical interest to ascertain the relation between the density of the sample and its thermal conductivity, but sufficient material has not been available for such tests. The conductivity of some of the material in sheet form has been determined and varied from about 0.00009 to 0.00012 C.G.S. units, the actual value being dependent, apparently, upon the precise method of manufacture, etc.

Now the weight per cubic foot of the samples tested was only about 5 to $7 \mathrm{lbs}$., whereas slab cork weighs i I to I 3 lbs. so that when comparisons are made on the basis of the weight of equivalent amounts of insulation the rubber shows a marked saving.

Tests of the insulating value of expanded rubber clippings when packed into an interspace have also been carried out. The clippings had been prepared from a sheet and measured roughly $\frac{1}{2}$ inch $\times \frac{1}{4}$ inch $\times \frac{1}{4}$ inch blocks with considerable variations from the mean. A density determination on some of the fragments gave the value $0.09 \pm 02$, i.e. $5.62 \pm 1 \cdot 25 \mathrm{lbs}$. per cubic foot.

In the test the material was evenly packed on either side of a hot plate measuring 8 inches by 8 inches surrounded by a 2 inch guard ring. The thickness of each layer was $\mathrm{I} \frac{1}{8}$ inches.

In the first test the packing was light, the material being pressed down slightly. The weight of material per cubic foot under these conditions was $2 \cdot 6$ lbs.

The data obtained are given in Table I. below.

The material was then taken out of the apparatus and repacked uniformly, but pressing in as much as possible. The weight of material per

\footnotetext{
IData as to the thermal conductivity of these materials vill be found in Speciai Report No. 5 of the Food Investigation Board entitled Report on Heat Instilators, published by H.M. Stationery Office.

${ }^{2}$ The density of ordinary red rabber vulcanised is variable. 'Two samples gave I.3 $\mathrm{I}$ and $\mathrm{r} \cdot 77$, i.e. $8 \mathrm{z}$ and $\mathrm{r}$ ro lbs. pher cubic foot respectively.
} 
cubic foot under these conditions was $4 \mathrm{lbs}$. The closer packing has increased the insulating efficiency by 12 per cent. (See Table I.)

So it would appear that in a granulated form the same insulating efficiency can be obtained with approximately half the weight of this material, as compared with granulated cork and about one-quarter the weight when compared with slab cork.

A somewhat parallel case to this, as regards the difference in weight per cubic foot, granulated and in sheets, is given by cork. In the baked slab form cork weighs about twice as much as the granulated and gives roughly the same insulating efficiency.

Since it is possible to control, in the course of manufacture, the density of the expanded rubber it would be of interest to ascertain the limit to which the reduction in density can be carried.

\section{TABLE 1 .}

Clippings of Expanded Rurber.

Density of Packing, $2.6 \mathrm{lbs}$. per cubic foot.

\begin{tabular}{|c|c|c|c|c|c|c|c|c|c|}
\hline \multirow{3}{*}{ Date. } & \multirow{3}{*}{ Time. } & \multirow{2}{*}{\multicolumn{2}{|c|}{$\begin{array}{l}\text { Cold Face } \\
\text { Temperatures. }\end{array}$}} & \multirow{2}{*}{\multicolumn{2}{|c|}{$\begin{array}{c}\text { Hot Face } \\
\text { Temperatures. }\end{array}$}} & \multirow{2}{*}{\multicolumn{2}{|c|}{$\begin{array}{c}\text { Mean Temp. } \\
\text { of the } \\
\text { Material. }\end{array}$}} & \multicolumn{2}{|c|}{ Conductivities. } \\
\hline & & & & & & & & & B.T.U.'s per \\
\hline & & o cent. & ${ }^{\circ}$ Fahr. & ${ }^{\circ}$ Cert. & ${ }^{\circ}$ Fahr. & ${ }^{\circ}$ Cent. & ${ }^{\circ}$ Fahr. & & in Temp. \\
\hline $\begin{array}{cc}\text { Aug. } & 7^{\text {th }} \\
, " & 8 \text { th } \\
", & 9 \text { th }\end{array}$ & $\mid \begin{array}{r}\text { I I A.M. } \\
9 \text { A.M. } \\
\text { I2 A.M. }\end{array}$ & $\begin{array}{l}20 \\
20 \\
20\end{array}$ & $\begin{array}{l}68 \\
68 \\
6 ;\end{array}$ & $\begin{array}{l}50 \\
50 \\
50\end{array}$ & $\begin{array}{l}122 \\
122 \\
122\end{array}$ & $\begin{array}{l}35 \\
35 \\
35\end{array}$ & $\begin{array}{l}95 \\
95 \\
95\end{array}$ & $\begin{array}{l}\text { 0*0oor } 22 \\
\text { o*ooori } 7 \\
\text { o*oooris }\end{array}$ & $\begin{array}{l}0.343 \\
0.340 \\
0.342\end{array}$ \\
\hline & & & & & & robable & value & 0.000118 & 0.342 \\
\hline
\end{tabular}

Density of Packitug, $4^{\circ} \mathrm{olbs}$. per cubic foot.

\begin{tabular}{|c|c|c|c|c|c|c|c|c|c|c|}
\hline \multirow{3}{*}{$\begin{array}{c}\text { Aug. } \\
\text { ", }\end{array}$} & I3th & I I A.M. & 20 & 68 & 50 & I 22 & 35 & 95 & 0.000105 & 0.305 \\
\hline & $\mathrm{r}_{4}$ th & 9 А.м. & 20 & 68 & 50 & 122 & 35 & 95 & 0.000107 & $0^{\circ} 3 \mathrm{II}$ \\
\hline & I $5^{\text {th }}$ & IO A.M. & 20 & 68 & 50 & 122 & 35 & 95 & 0.000105 & 0.305 \\
\hline \multicolumn{9}{|c|}{ Probable value } & 0.000106 & 0.308 \\
\hline
\end{tabular}

The material differs markedly from ordinary vulcanised red rubber in its properties, a notable characteristic being its softness. The questions of the durability of the material under rough usage and its chemical stability are ones which merit careful investigation.

Rubber is permeable to water vapour and to many gases, so the gas cells cannot be regarded as hermetically sealed. A sample of the material tested under water for a period of 300 hours showed a progressive increase of weight with time. It cannot yet be stated whether this water absorption is due to water vapour permeating the rubber and forming an adsorbed film on the surface of the cells, or whether it is due to capillary absorption similar to the effect obtained with charcoal. The fact that the action is slow would appear to indicate that it is due to water vapour permeating through the rubber, but it must be remembered that in the case of capillary attraction the action would be slow if the capillaries were close-ended and the water had to dissolve the gas as it flowed along the capillary. 
The constitution of the material does not appear to be simply one of gas enclosed in cavities with solid rubber walls, and it is probable that an appreciable amount of gas is absorbed in the rubber. The determination of the state in which the gas is present in the material is a perplexing chemical problem.

In the present stage of our knowledge concerning this new material, it is difficult to express an opinion as to its value as a practical heat insulator for lining the walls of a store. A long period test on a reasonably large scale is really essential, and the quantity of material necessary for such a test has not yet become available.

Balsa Wood.-Balsa is the wood of a large tropical tree growing in Ecuador. It is probably the lightest wood known. The samples we have tested have varied in weight from 5.7 to $8.6 \mathrm{lbs}$. per cubic foot. ${ }^{1}$

As a structural material it is decidedly weak and liable to damage by blows, etc., but it has the advantage over materials such as cork that it can be worked with ordinary wood-working tools which, however, must be very sharp and run at high speed.

In the natural state the wood is subject to decay, but it is claimed that with preservatives it is possible to make the wood sufficiently waterproof to enable it to be used for cold storage insulation.

When the material is to be employed in dry situations it can be surfaced with a veneer of hard wood.

The results of tests on several varieties of the material are given in Table II. below :--

TABLE II.

BALSA WOOD.

Specimen of $2^{\prime \prime}$ Board weighing $5{ }^{\circ} 75$ lbs. per cubic foot.

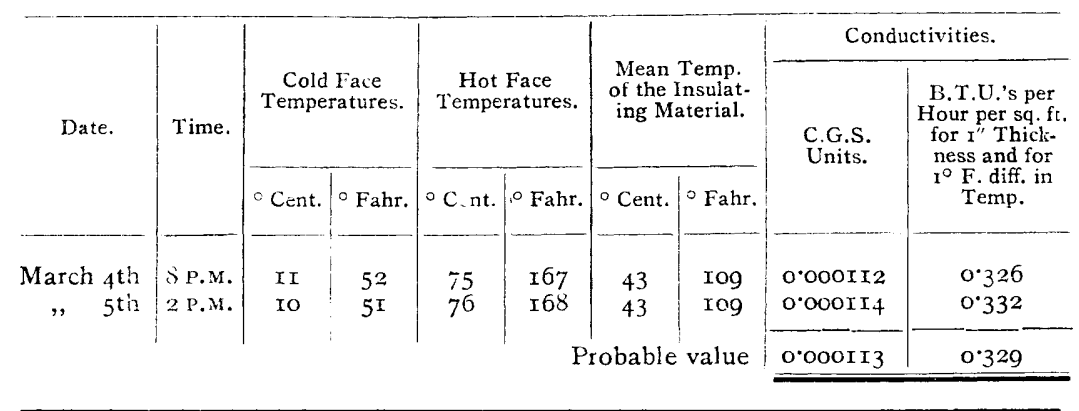

Specimeil of 2" Treated Board weighing 8.6 lbs. per cubic foot.

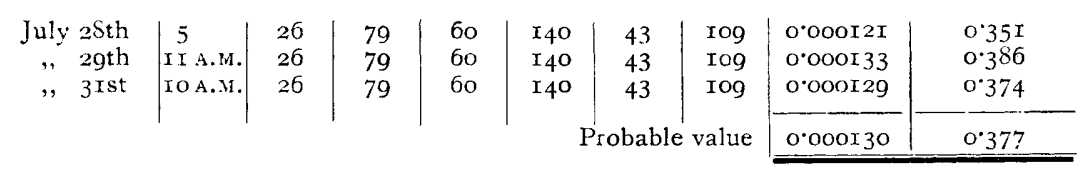

Fibres of Kingia Australis. - The possibility of using this material

This may be compared with mahogany, which werghs about $45 \mathrm{lbs}$. per cubic foot. 
was suggested by Mr. R. A. Fowler, Forest Produce Laboratory, Perth, Australia, who supplied the following information concerning it.

It is a fibrous waste from a tree known as "Kingia Australis." This plant is peculiar to Western Australia where it grows on the poorer soils of the coastal belt. The tree consists of a long cylindrical stem up to about 20 feet high and a foot in diameter, surmounted by a tuft of long grass-like leaves. The stems are usually black in outward appearance, owing to charring by forest fires, and are composed of an outer sheath of persistent leaf bases packed very closely together, an inner sheath an inch to 2 inches in thickness of longitudinal fibres cemented together in a close matrix, and an inner core of closely packed short fibres. The inner sheath of long fibres is the only portion of the plant at present used.

A waste product is obtained in cleaning the fibres from the cementing matrix in the form of dust and fibrous material.

The results of a series of tests on this material are given in Table III. below :-

TABLE III.

Fibres of Wood, Kingia Australis.

Density of Packing, $8 \cdot 4$ lbs. per cubic foot.

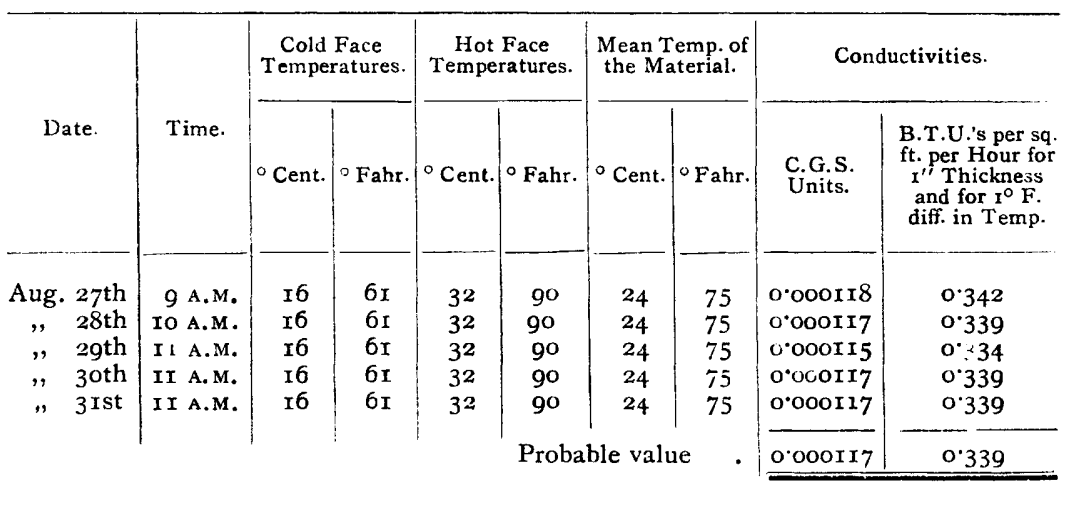

Eel Grass Mats.- This material is made up of cured eel-grass sewn in between sheets of strong paper. The grass grows in salt water and contains silicon to a large extent. It does not harbour insects or vermin, which is a most valuable characteristic.

The value of eel grass as a thermal insulator appears to have been realised at an early date in the United States, for it is stated that a dwelling house built in 1635 in Dorchester, Mass., was lined with the grass stuffed between the studding, and the material appears to have been in a gocd state of preservation after a lapse of more than two and a half centuries.

A sample of commercial matting was obtained and tested in two states of packing. The results are given in Table IV.

Whether the material will meet the stringent requirements of the refrigerating engineer is a matter for experiment under service conditions. 
TABLE IV.

Eel Grass Mats.

Donsity of Packing, $9^{\circ}+$ lbs. per cubic foot.

\begin{tabular}{|c|c|c|c|c|c|c|c|c|c|c|}
\hline \multirow{3}{*}{\multicolumn{2}{|c|}{ Late. }} & \multirow{3}{*}{ Time. } & \multirow{2}{*}{\multicolumn{2}{|c|}{$\begin{array}{c}\text { Cold Face } \\
\text { Temperatures. }\end{array}$}} & \multirow{2}{*}{\multicolumn{2}{|c|}{$\begin{array}{c}\text { Hot Face } \\
\text { Temperatures. }\end{array}$}} & \multirow{2}{*}{\multicolumn{2}{|c|}{$\begin{array}{c}\text { Mean Temp. } \\
\text { of the } \\
\text { Material. }\end{array}$}} & \multicolumn{2}{|c|}{ Conductivities. } \\
\hline & & & & & & & & & \multirow{2}{*}{$\begin{array}{l}\text { G.G,S. } \\
\text { Units. }\end{array}$} & \multirow{2}{*}{$\begin{array}{l}\text { B.T.U.'s per } \\
\text { sq. ft. per } \\
\text { Hour for I" } \\
\text { Thickness and } \\
\text { for I F. difi. } \\
\text { in Temp. }\end{array}$} \\
\hline & & & Cent. & - Fahr & o Cent. & Fahr. & - Cent. & Fahr. & & \\
\hline \multirow[t]{2}{*}{$\begin{array}{c}\text { May } \\
, "\end{array}$} & $\begin{array}{l}8 \text { th } \\
9 \text { th }\end{array}$ & $\begin{array}{l}\text { IOA.M. } \\
\text { 9A.M. }\end{array}$ & $\begin{array}{l}\text { I5 } \\
\text { I5 }\end{array}$ & $\begin{array}{l}59 \\
59\end{array}$ & $\begin{array}{l}45 \\
45\end{array}$ & $\begin{array}{l}\text { II } 3 \\
\text { Ir } 3\end{array}$ & $\begin{array}{l}30 \\
30\end{array}$ & $\begin{array}{l}86 \\
86\end{array}$ & $\begin{array}{l}\text { o.ooorog } \\
\text { o.00oIo } 8\end{array}$ & $\begin{array}{l}0.3 \text { I8 } \\
0 \cdot 3 \text { I } 4\end{array}$ \\
\hline & & & & & \multicolumn{4}{|c|}{ Probable value } & $0.000 \operatorname{ros}_{5}$ & $0 \cdot 316$ \\
\hline
\end{tabular}

Density of Packing, $\mathrm{x}_{3}{ }_{4}$ lls. per cubic foot.

\begin{tabular}{|c|c|c|c|c|c|c|c|c|c|c|}
\hline $\begin{array}{c}\text { May } \\
\text {," }\end{array}$ & $\begin{array}{l}\text { r6th } \\
\text { r } 7^{\text {th }}\end{array}$ & $\begin{array}{l}\text { II A.M.: } \\
\text { II A.M. }\end{array}$ & $\begin{array}{l}\text { I9 } \\
\text { I9 }\end{array}$ & $\begin{array}{l}66 \\
66\end{array}$ & $\begin{array}{l}4 \mathrm{I} \\
4 \mathrm{I}\end{array}$ & $\begin{array}{l}\text { ro6 } \\
\text { Io6 }\end{array}$ & $\begin{array}{l}30 \\
30\end{array}$ & $\begin{array}{l}86 \\
86\end{array}$ & $\begin{array}{l}0.000 \text { Ir } 7 \\
\text { 0.000II } 7\end{array}$ & $\begin{array}{l}0.34 \mathrm{I} \\
0.34 \mathrm{I}\end{array}$ \\
\hline & & & & & & \multicolumn{3}{|c|}{ Probable value } & 0.000II 7 & $0.34 \mathrm{r}$ \\
\hline
\end{tabular}

Compressed Peat.-Peat, variously treated, is being extensively used on the Continent for heat insulation. The chief merit of the material is its cheapness. For cold storage work the peat is impregnated with a bituminous substance to protect it from the effect of damp. Data concerning tests on "treated" and " untreated" material are given in Table V. below.

The heavy weight per cubic foot of the material-20 to $30 \mathrm{lbs}$. - is a disadvantage.

TABLE V.

Compressed Peat.

Weight of Specimen, zo lbs. per cubic foot.

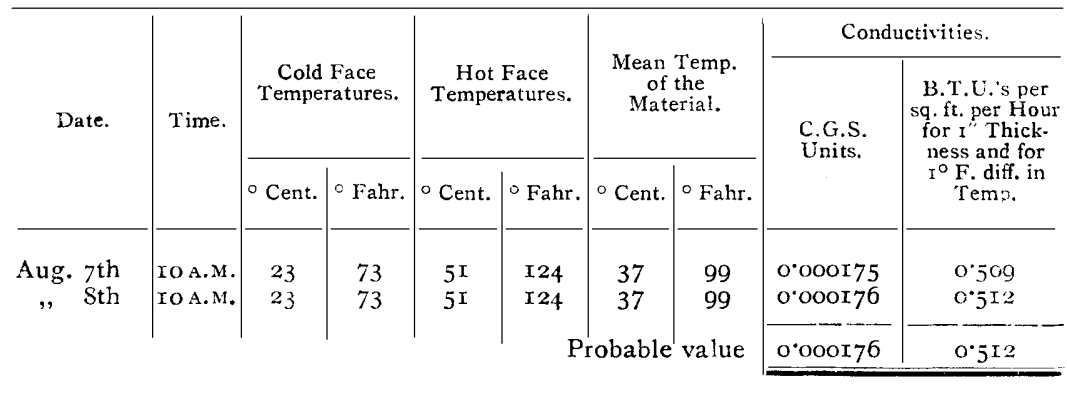

Peat Treated with Bituminous Material.

Weight of Specimen, 29.5 lbs. per cubic foot.

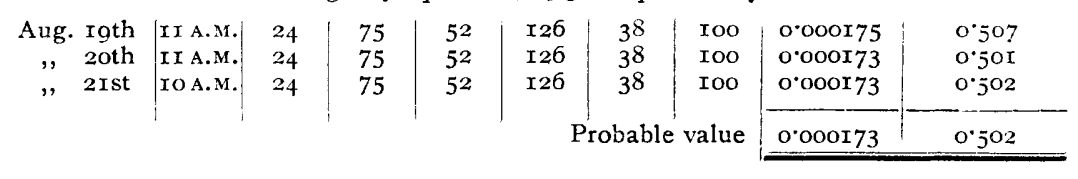

A sample obtained from another source gave the value $0^{\circ}$ ooor67 C.G.S. units for the thermal conductivity at $38^{\circ} \mathrm{C}$. 


\section{SOME MATERIALS OF LOW THERMAL CONDUCTIVITY}

In conclusion it may be pointed out that the thermal conductivity of insulating materials in general is not an invariable physical constant. So it follows that it is advisable to test samples of various consignments just as it is desirable to determine the calorific value of a fuel.

The experiments recorded in this paper and the other on Thermometric Lag constitute a part of the programme of work for the Engineering Committee of the Food Investigation Board.

We desire to record our thanks to the Engineering Committee and to our director for their interest and encouragement. 